\title{
Modulation of $\alpha_{2}$-Adrenoceptor Functions by Heterotrimeric $\mathrm{G} \alpha_{\mathrm{i}}$ Protein Isoforms
}

\author{
Julián Albarrán-Juárez, Ralf Gilsbach, Roland P. Piekorz, Katja Pexa, Nadine Beetz, \\ Johanna Schneider, Bernd Nürnberg, Lutz Birnbaumer, and Lutz Hein \\ Institute of Experimental and Clinical Pharmacology and Toxicology, University of Freiburg, Germany (J.A.-J., R.G., N.B., J.S., \\ L.H.); Institute of Biochemistry and Molecular Biology II, Heinrich-Heine-University, Düsseldorf, Germany (R.P.P., K.P., B.N.); \\ Institute of Experimental and Clinical Pharmacology and Toxicology, and Interfaculty Center of Pharmacogenomics and \\ Pharmaceutical Research, Eberhard-Karls-University, Tübingen, Germany (B.N.); and Laboratory of Neurobiology, National \\ Institute of Environmental Health Sciences, National Institutes of Health, Research Triangle Park, North Carolina (L.B.)
}

Received June 4, 2009; accepted July 8, 2009

\begin{abstract}
Subtype diversity of heterotrimeric $G$ proteins and $G$ proteincoupled receptors enables a wide spectrum of signal transduction. However, the significance of isoforms within receptor or $G$ protein subfamilies has not been fully elucidated. In the present study, we have tested whether $\alpha_{2}$-adrenoceptors require specific $\mathrm{G} \alpha$ isoforms for their function in vivo. In particular, we analyzed the role of the highly homologous $\mathrm{G} \alpha_{\mathrm{i}}$ isoforms, $\mathrm{G} \alpha_{\mathrm{i} 1}$, $\mathrm{G} \alpha_{\mathrm{i} 2}$, and $\mathrm{G} \alpha_{\mathrm{i} 3}$, in typical $\alpha_{2}$-adrenoceptor-controlled functions. Mice with targeted deletions in the genes encoding $\mathrm{G} \alpha_{\mathrm{i} 1}, \mathrm{G} \alpha_{\mathrm{i} 2}$, or $\mathrm{G} \alpha_{\mathrm{i} 3}$ were used to test the effects of $\alpha_{2}$-adrenoceptor stimulation by the agonist medetomidine. The $\alpha_{2}$-adrenoceptor agonist medetomidine inhibited $\left[{ }^{3} \mathrm{H}\right]$ norepinephrine release from isolated prefrontal brain cortex or cardiac atria tissue specimens with similar potency and efficacy in tissues from wildtype or $\mathrm{G} \alpha_{\mathrm{i}}$-deficient mice. In vivo, bradycardia, hypotension, induction of sleep, antinociception, and hypothermia induced
\end{abstract}

by $\alpha_{2}$-adrenoceptor activation did not differ between wild-type and $\mathrm{G} \alpha_{\mathrm{i}}$-knockout mice. However, the effects of the $\alpha_{2}$-agonists medetomidine or 5-bromo-6-(2-imidazolin-2-ylamino)quinoxaline tartrate (UK14,304) on spontaneous locomotor activity or anesthetic sparing were reduced or absent, respectively, in mice lacking $\mathrm{G} \alpha_{\mathrm{i} 2}$. In microdissected locus coeruleus neurons or postganglionic sympathetic neurons from stellate ganglia, all three $\mathrm{G} \alpha_{\mathrm{i}}$ subunits were expressed as determined by quantitative reverse transcription-polymerase chain reaction, with $\mathrm{G} \alpha_{\mathrm{i} 1}$ and $\mathrm{G} \alpha_{\mathrm{i} 2}$ dominating over $\mathrm{G} \alpha_{\mathrm{i} 3}$. Functional redundancy of the highly homologous $\mathrm{G} \alpha_{\mathrm{i}}$ isoforms may predominate over specificity to regulate distinct intracellular pathways downstream of $\alpha_{2}$-adrenoceptors in vivo. In contrast, inhibition of locomotor activity and anesthetic sparing may be elicited by a specific coupling of $\alpha_{2 \mathrm{~A}}$-adrenoceptors via the $\mathrm{G} \alpha_{\mathrm{i} 2}$ isoform to intracellular pathways.
Heterotrimeric $\mathrm{G}$ proteins are composed of $\alpha, \beta$, and $\gamma$ subunits and play diverse roles in many aspects of cell regulation. In general, $\mathrm{G}$ proteins are classified according to the intracellular signaling pathway stimulated by their $\alpha$ subunits, although growing evidence is supporting a regulatory role for the tightly associated $\beta \gamma$ dimers (Gibson and Gilman, 2006; Smrcka, 2008). Agonist activation of G protein-coupled

This study was supported in part by the Intramural Research Program of the National Institutes of Health National Institute of Environmental Health Sciences [Grant ES101643] (to L.B.); the Deutsche Forschungsgemeinschaft [Grant DFG PAK 350/1, TP A2 (to L.H., R.G.), SFB 612, TP A8 (to B.N., R.P.P.), and GRK 1089, TP 2 (to B.N., R.P.P.)]; an intramural grant from the Forschungskommission of the Medical Faculty of the Heinrich-Heine-University (Düsseldorf, Germany) (to R.P.P.); and the Deutscher Akademischer Austausch Dienst (to J.A.-J.)

J.A.-J. and R.G. contributed equally to this work.

Article, publication date, and citation information can be found at http://jpet.aspetjournals.org.

doi:10.1124/jpet.109.157230. receptors induces a conformational change within the receptor, which subsequently catalyzes the exchange of GDP for GTP on the $\mathrm{G} \alpha$ subunit leading to the dissociation of the heterotrimer into the GTP-bound $\mathrm{G} \alpha$ subunit and the functional G $\beta \gamma$ dimer (Gilman, 1987). These two mediators relay signals from the receptor to several downstream effectors, including ion channels, small GTPases, adenylyl cyclases, phosphodiesterases, and phospholipases, giving rise to the generation of respective second messenger molecules involved in regulating physiological processes (Offermanns, 2003).

Based on their sequence homology and differential regulation of effectors, G proteins are grouped into four functional classes: $\mathrm{G} \alpha_{\mathrm{s}}$, increasing the levels of cAMP via adenylyl cyclase; $\mathrm{G} \alpha_{i}$, decreasing cAMP levels by inhibition of adenylyl cyclase or modulating potassium channels; $\mathrm{G} \alpha_{\mathrm{q}}$, activating phospholipase $\mathrm{C} \beta$ and eventually leading to a rise in intra-

ABBREVIATIONS: WT, wild type; UK14,304, 5-bromo-6-(2-imidazolin-2-ylamino)quinoxaline tartrate; PCR, polymerase chain reaction; PBS, phosphate-buffered saline; KO, knockout. 
cellular calcium; and $\mathrm{G}_{12 / 13}$, interacting with chloride channels and other second messenger systems (Morris and Malbon, 1999) and activating the small GTPase Rho involved in actin cytoskeleton reorganization (Wettschureck and Offermanns, 2005).

Members of the $\alpha_{2}$-adrenoceptor family are prototype $G_{i}$ protein-coupled receptors involved in the regulation of a wide number of physiological functions in vivo, including presynaptic inhibition of norepinephrine secretion from sympathetic nerves (Hein et al., 1999; Gilsbach et al., 2009), bradycardia and hypotension (MacMillan et al., 1996), analgesia and sedation (Lakhlani et al., 1997), body temperature, and intraocular pressure. The $\mathrm{G}_{\mathrm{i}}$ subfamily of $\mathrm{G} \alpha$ subunits comprises three highly related members, $\mathrm{G} \alpha_{\mathrm{i} 1}, \mathrm{G} \alpha_{\mathrm{i} 2}$, and $\mathrm{G}_{\mathrm{i} 3}$ (Gerhardt and Neubig, 1991; Nürnberg et al., 1995), which are characterized by their sensitivity to pertussis toxin. The three $\mathrm{G} \alpha_{\mathrm{i}}$ subunits are encoded by distinct genes, termed Gnai1, Gnai2, and Gnai3 (Offermanns, 2003). These $\mathrm{G} \alpha_{\mathrm{i}}$ isoforms share an amino acid sequence identity of higher than $85 \%$ and are characterized by partially overlapping expression patterns. In particular, $\mathrm{G \alpha}_{\mathrm{i} 1}$ is primarily found in the nervous system, whereas $\mathrm{G} \alpha_{\mathrm{i} 2}$ is expressed ubiquitously and represents the quantitatively predominant $\mathrm{G} \alpha_{\mathrm{i}}$ isoform. Last, $\mathrm{G} \alpha_{\mathrm{i} 3}$, the closest homolog of $\mathrm{G} \alpha_{\mathrm{i} 1}$, is hardly detectable at the protein level in the neuronal system but is broadly expressed in peripheral tissues (Nürnberg, 2004).

The functional significance of $G_{i}$ proteins and in particular the possible specificity of $\mathrm{G} \alpha_{i}$ isoforms in $\alpha_{2}$-adrenoceptordependent signal transduction in vivo have not been fully explored. Here, we used mice with targeted deletions of individual $\mathrm{G} \alpha_{\mathrm{i}}$ isoforms to examine for the first time their role in physiological functions mediated by $\alpha_{2}$-adrenoceptor activation, i.e., inhibition of locomotor activity, induction of sleep, sedation/anesthetic-sparing, antinociception, hypothermia, bradycardia, and hypotension.

\section{Materials and Methods}

Animals. All experiments were performed on four groups of mice: wild type (WT) and $\mathrm{G}_{\alpha_{11^{-}}}, \mathrm{G}_{\alpha_{\mathrm{i} 2^{-}}}$, and $\mathrm{G} \alpha_{\mathrm{i} 3}$-deficient mice, respectively. Generation and characterization of mouse models with targeted deletion of genes encoding for $\mathrm{G} \alpha_{i}$ proteins has been described previously (Rudolph et al., 1995; Jiang et al., 2002; Pineda et al., 2004; Gohla et al., 2007). G $\alpha_{\mathrm{i}}$-deficient mice were backcrossed onto a C57BL6/J background for $>11$ generations. Adult mice (3-5 months of age; $20-25 \mathrm{~g}$ body weight) were maintained on a 12-h light/dark cycle in specified pathogen-free facilities with unlimited access to food and water. All animal procedures were approved by the animal care committee of the University of Freiburg and were carried out in accordance with the Guide for the Care and Use of Laboratory Animals as adopted and promulgated by the National Institutes of Health (Bethesda, MD).

$\left[{ }^{3} \mathbf{H}\right]$ Norepinephrine Release. Pieces of prefrontal cortex were prepared from each animal after cervical dislocation as described previously (Trendelenburg et al., 2001). Tissue specimens from cardiac atria were processed as described previously (Altman et al., 1999; Hein et al., 1999). In brief, tissue segments were preincubated in $1 \mathrm{ml}$ of medium containing $0.1 \mu \mathrm{M}\left[{ }^{3} \mathrm{H}\right]$ norepinephrine (GE Healthcare, Freiburg, Germany) for $30 \mathrm{~min}$ at $37^{\circ} \mathrm{C}$. Segments were then placed in superfusion chambers between platinum electrodes, one segment per chamber, in which they were superfused with $\left[{ }^{3} \mathrm{H}\right]$ norepinephrine-free medium at a rate of $1.2 \mathrm{ml} / \mathrm{min}$. Successive 2 -min samples of the superfusate were collected from $t=50 \mathrm{~min}$ onward ( $t=0 \mathrm{~min}$ being the start of superfusion). Six periods of electrical stimulation with pseudo-one pulse conditions (prefrontal cortex, 4 pulses/100 Hz; atria, 20 pulses/100 Hz; 2-ms pulse width; 80-mA amplitude) were applied at 8-min intervals. Concentrationresponse curves for the release-inhibiting effect of medetomidine were determined by addition of this $\alpha_{2}$-agonist at increasing concentrations. At the end of experiments, tissues were dissolved and tritium was determined in superfusate samples and tissues. The superfusion medium contained $118 \mathrm{mM} \mathrm{NaCl}, 4.8 \mathrm{mM} \mathrm{KCl}, 1.3 \mathrm{mM}$ $\mathrm{CaCl}_{2}$ (cortex), $1.2 \mathrm{mM} \mathrm{MgSO}$, $25 \mathrm{mM} \mathrm{NaHCO}_{3}, 1.2 \mathrm{mM} \mathrm{KH} \mathrm{KO}_{4}$, $11 \mathrm{mM}$ glucose, $0.57 \mathrm{mM}$ ascorbic acid, $0.03 \mathrm{mM}$ disodium EDTA, and $0.001 \mathrm{mM}$ desipramine (Hein et al., 1999).

The outflow of tritium was calculated as fraction of the tritium content of the tissue at the onset of the respective collection period (fractional rate; minutes $^{-1}$ ). The overflow elicited by electrical stimulation was calculated as the difference "total tritium outflow during and after stimulation" minus "basal outflow" and was then expressed as a percentage of the tritium content of the tissue at the time of stimulation (Trendelenburg et al., 2001, 2003). The calculation yielded the $E_{\max }$ value and $\mathrm{EC}_{50}$ value of medetomidine (concentration causing half-maximal inhibition), and $n$ is the number of superfusion chambers (containing one piece of tissue).

Spontaneous Locomotor Activity. Locomotor activity was measured by placing individual animals into a transparent polypropylene animal cage $(25 \times 19 \times 13 \mathrm{~cm})$ with a 1 -cm-thick layer of granulated bedding on the floor. The cages were surrounded by a custom-made infrared photobeam frame designed to measure activity. The baseline locomotor activity was measured over 10-min intervals for 30 min before and after administration of $0.9 \%$ saline or medetomidine $(50 \mu \mathrm{g} / \mathrm{kg}$ i.p.) $(n=6-8$ male mice/genotype group; age 12-16 weeks). Medetomidine (4-[1-(2,3-dimethylphenyl)ethyl]$1 \mathrm{H}$-imidazole hydrochloride) was a gift from Orion Pharma (Espoo, Finland). UK14,304 was obtained from Tocris Bioscience (Bristol, UK).

Loss of Righting Reflex and Anesthetic-Sparing Effect. Loss of the righting reflex was used as a measure of sedation. For this test, mice received intraperitoneal injections of medetomidine (50, 100, $200,500,750$, or $1000 \mu \mathrm{g} / \mathrm{kg}$ i.p.). In a separate series of experiments, the sedative response to pentobarbital (50 $\mathrm{mg} / \mathrm{kg}$ i.p.) was assessed. To assess the anesthetic sparing effect of $\alpha_{2}$-adrenoceptor stimulation, mice received saline or medetomidine (50 or $100 \mu \mathrm{g} / \mathrm{kg}$ i.p.). Thirty minutes later, mice were placed in an airtight Plexiglas chamber, and isoflurane was administered at stepwise increasing concentrations for 5 min per concentration $\left(0-1.2\right.$ vol\% in $\left.\mathrm{O}_{2}\right)$. Loss of the righting reflex was assessed at the end of each 5 -min period. Mice were laid on their back and allowed to right themselves within $30 \mathrm{~s}$ (Gilsbach et al., 2009).

Antinociception. The pain threshold was measured in WT, $\mathrm{G} \alpha_{\mathrm{i} 1^{-}}, \mathrm{G} \alpha_{\mathrm{i} 2^{-}}$, or $\mathrm{G} \alpha_{\mathrm{i} 3}$-deficient mice, respectively, by the tail-flick method (Harvard Apparatus, Les Ulis, France). A high-intensity light was focused on the distal two thirds of mouse tail, and the time to flick their tail was automatically recorded and determined as the tail-flick latency (in seconds). A cut-off of $15 \mathrm{~s}$ and exposing a different part of the tail to the beam on each trial were applied to prevent the risk of tissue damage. The tail-flick latencies were determined 30 min after administration of saline or medetomidine (100 or $200 \mu \mathrm{g} / \mathrm{kg}$ i.p.).

Body Temperature. Core body temperature of the mice was monitored at the end of the anesthetic sparing experiments and was thus recorded $60 \mathrm{~min}$ after administration of drug or vehicle using a rectal thermometer probe (TKM-0902; FMI, Seeheim-Ober Beerbach, Germany). Experiments were carried out at an ambient temperature of $23 \pm 2^{\circ} \mathrm{C}$.

Hemodynamic Measurements. For aortic catheterization with a 1.4-French pressure-volume catheter (Millar Instruments Inc., Houston, TX), mice were anesthetized with isoflurane $\left(2\right.$ vol\% in $\left.\mathrm{O}_{2}\right)$ and placed on a $37^{\circ} \mathrm{C}$ plate (Brede et al., 2002). The microtip catheter was inserted via the right carotid artery and advanced into the ascending aorta for pressure measurements. Medetomidine (6.5-330 
$\mu \mathrm{g} / \mathrm{kg}$ body weight in six doses) was applied via the left jugular vein. Each dose was infused over $1 \mathrm{~min}$.

Locus Coeruleus Microdissection. For microscopical microdissection of locus coeruleus specimens, tissues were frozen in liquid nitrogen. Then, $15-\mu \mathrm{m}$ cryostat sections were mounted on glass slides and dehydrated in ethanol and xylene, followed by microdissection using an AM6000 inverted microscope (Leica, Wetzlar, Germany). The area of the locus coeruleus (Paxinos and Franklin, 2001) was microdissected using MicroChisels (Eppendorf, Hamburg, Germany) and aspirated via a micropipette. Xylene was evaporated and RNA was isolated using the RNeasy Micro kit (QIAGEN, Hilden, Germany). The identity of the locus coeruleus was verified by quantitative real-time PCR-based analysis of tyrosine hydroxylase and dopamine $\beta$-hydroxylase expression.

Immunohistochemistry. For immunodetection of adrenergic neurons in the locus coeruleus or sympathetic ganglia, cryostat sections from perfusion-fixed mice [4\% paraformaldehyde and $0.1 \%$ glutaraldehyde in phosphate-buffered saline (PBS)] were used. Sections were blocked in $1 \%$ bovine serum albumin, $0.04 \%$ Triton X-100 in PBS, and incubated overnight with an anti-tyrosine hydroxylase antiserum, followed by Alexa488-coupled secondary antibodies.

Quantitative Real-Time PCR. mRNA quantification by realtime PCR from murine tissues was performed as described previously (Gilsbach et al., 2007). For quantitative real-time PCR, $30 \mu \mathrm{l}$ of the amplification mixture (Quantitect SYBR Green kit; QIAGEN) was used containing $20 \mathrm{ng}$ of reverse-transcribed RNA and $300 \mathrm{nM}$ primers (MWG, Ebersberg, Germany) specific for $\mathrm{G} \alpha_{\mathrm{i}}$ subunits or the ribosomal protein S29 (Table 1). Reactions were run in triplicate on an MX3000P detector (Stratagene, Amsterdam, The Netherlands). The cycling conditions were as follows: 15 -s polymerase activation at $95^{\circ} \mathrm{C}$ and 40 cycles at $95^{\circ} \mathrm{C}$ for $15 \mathrm{~s}$, at $58^{\circ} \mathrm{C}$ for $30 \mathrm{~s}$, and at $72^{\circ} \mathrm{C}$ for $30 \mathrm{~s}$. Absolute copy numbers were determined using standard curves of corresponding linear DNA fragments (Gilsbach et al., 2007).

Statistical Analysis. Data are presented as means \pm S.E.M. of individual data points. Data were analyzed using one or two-way analysis of variance or Kruskal-Wallis test (ratios) followed by appropriate post hoc tests. A $p$ value of less than 0.05 was considered as statistically significant.

\section{Results}

Feedback Control of Norepinephrine Release from Sympathetic Nerves. To evaluate whether a distinct $\mathrm{G} \alpha_{\mathrm{i}}$ isoform mediates the feedback inhibition of norepinephrine release from sympathetic nerves after $\alpha_{2}$-adrenergic activation, the inhibition of electrically evoked release of $\left[{ }^{3} \mathrm{H}\right]$ norepinephrine by the $\alpha_{2}$-adrenoceptor agonist medetomidine was tested in prefrontal brain cortex slices (Fig. 1; Table 2) and cardiac atria (Table 2) isolated from wild-type or $\mathrm{G}_{\mathrm{i}^{-}}{ }^{-}$ deficient mice. Neurotransmitter release was elicited by short pulse trains of electrical field stimulation (Fig. 1a). In brain cortex, electrically evoked maximal release of $\left[{ }^{3} \mathrm{H}\right]$ norepinephrine did not differ between tissue specimens from wild-type or $\mathrm{G} \alpha_{\mathrm{i}}$-deficient mice (data not shown). In the presence of increasing concentrations of medetomidine, $\left[{ }^{3} \mathrm{H}\right]$ norepinephrine release was inhibited to a similar degree in tissue slices from all genotypes analyzed (Fig. 1, b-d; Table 1). The $\mathrm{EC}_{50}$ values for the inhibitory effect of medetomidine did not differ significantly between genotype groups (Fig. 1, b-d; Table 2). Similar results were obtained for inhibition of $\left[{ }^{3} \mathrm{H}\right]$ norepinephrine release from isolated cardiac atria. Concentrations of medetomidine to inhibit transmitter release from isolated atria by $50 \%$ did not differ significantly between tissues obtained from $\mathrm{G}_{\mathrm{\alpha}_{\mathrm{i}}}$-deficient or wild-type animals (Table 2). These results indicate that a single $\mathrm{G} \alpha_{\mathrm{i}}$ isoform is not required in an essential/nonredundant manner to inhibit electrically evoked release of norepinephrine from adrenergic nerve terminals in the brain cortex or in cardiac atria.

Inhibition of Locomotor Activity. $\alpha_{2}$-Adrenoceptor agonists (e.g., clonidine and medetomidine) have been shown to elicit strong sedative and hypnotic effects via activation of $\alpha_{2 \mathrm{~A}}$-adrenoceptors (Lakhlani et al., 1997). Thus, we tested which $\mathrm{G} \alpha_{\mathrm{i}}$ isoform may be specifically required to inhibit spontaneous locomotor activity in a photobeam cage system (Fig. 2, a and b). Basal locomotor activity did not differ between genotypes (Fig. 2a). After intraperitoneal application of medetomidine $(50 \mu \mathrm{g} / \mathrm{kg})$, locomotor activity was reduced to $9.2 \pm 3.8 \%$ in wild-type mice, $7.9 \pm 3.7 \%$ in $\mathrm{G}_{\mathrm{i} 1}-\mathrm{KO}$ mice, and $4.3 \pm 3.3 \%$ in $\mathrm{G \alpha}_{\mathrm{i} 3}$-KO mice (Fig. $2 \mathrm{~b}$ ). However, the sedative effect of medetomidine was significantly attenuated in $\mathrm{G} \alpha_{\mathrm{i} 2}-\mathrm{KO}$ mice. Medetomidine reduced locomotor behavior to $37.2 \pm 8.1 \%$ in $\mathrm{G \alpha}_{\mathrm{i} 2}-\mathrm{KO}$ mice (Fig. $2 \mathrm{~b}$ ).

Loss of Righting Reflex and Anesthetic Sparing Induced by Medetomidine. Next, the effect of the $\alpha_{2}$-agonist medetomidine on the righting reflex and anesthetic sparing was assessed (Figs. 2 and 3). At first, loss of the righting reflex in response to intraperitoneal injection of medetomidine was assessed (Fig. 2c). At doses of 750 or $1000 \mu \mathrm{g} / \mathrm{kg}$ medetomidine, a strong sedative effect was induced in all genotype groups (Fig. 2c). At $750 \mu \mathrm{g} / \mathrm{kg}$ medetomidine, 7 of 14 WT mice (50\%), 12 of $16 \mathrm{G} \alpha_{\mathrm{i} 1}$-KO mice (75\%), 8 of $13 \mathrm{G} \alpha_{\mathrm{i} 2}$-KO mice $\left(61.5 \%\right.$ ), and 7 of $12 \mathrm{G} \alpha_{\mathrm{i} 3}-\mathrm{KO}$ mice (58.3\%) lost their righting reflex. Statistical evaluation did not reveal significant differences in the sedative response between wild-type animals and mice deficient in $\mathrm{G}_{\mathrm{i}}$ isoforms $(n=12-16$ mice/ genotype group; $p>0.05$ ).

To assess the sensitivity of $\mathrm{G} \alpha_{\mathrm{i}_{1}}, \mathrm{G} \alpha_{\mathrm{i} 2^{-}}$, and $\mathrm{G} \alpha_{\mathrm{i} 3}$-deficient mice to sedation through non- $\alpha_{2}$-adrenoceptor stimuli, animals received $50 \mathrm{mg} / \mathrm{kg}$ of the $\mathrm{GABA}_{\mathrm{A}}$ receptor agonist pentobarbital, and the time until loss or recovery (Fig. 2d) of the righting reflex was recorded. Similar to medetomidine treat-

TABLE 1

Primers used to determine $\mathrm{G} \alpha_{\mathrm{i}}$ isoform expression by quantitative reverse transcription-PCR

\begin{tabular}{|c|c|c|c|c|}
\hline Gene & Primer Sequence $\left[5^{\prime} \rightarrow 3^{\prime}\right]$ & & GenBank Accession No. & Product Size \\
\hline & & & & $b p$ \\
\hline \multirow[t]{2}{*}{$\mathrm{G} \alpha_{\mathrm{i} 1}$} & ACGATTCGGCAGCGTACT & $\mathrm{s}$ & NM_010305 & 72 \\
\hline & TCCTGCTGAGTTGGGATGTA & as & & \\
\hline \multirow{2}{*}{$\mathrm{G} \alpha_{\mathrm{i} 2}$} & GAGGTGAAGTTGCTTCTGTTAGG & $\mathrm{s}$ & NM_008138 & 77 \\
\hline & TTCATGGATGATCTTCATCTGC & as & & \\
\hline \multirow[t]{2}{*}{$\mathrm{G} \alpha_{\mathrm{i} 3}$} & GATTGATTTTGGGGAATCTGC & $\mathrm{s}$ & NM_010306 & 85 \\
\hline & AATCACGCCTGCTAGTTCTGA & as & & \\
\hline \multirow[t]{2}{*}{ Rps29 } & ATGGGTCACCAGCAGCTCTA & $\mathrm{s}$ & NM_009093 & 154 \\
\hline & AGCCTATGTCCTTCGCGTACT & as & & \\
\hline
\end{tabular}

bp, base pair; Rps29, ribosomal protein S29; s, sense; as, antisense. 
ment, the induction or recovery time of the hypnotic effect of pentobarbital did not differ significantly between the four genotype groups analyzed (Fig. 2d).

When given at smaller doses, $\alpha_{2}$-agonists have been shown

\section{a Norepinephrine release}
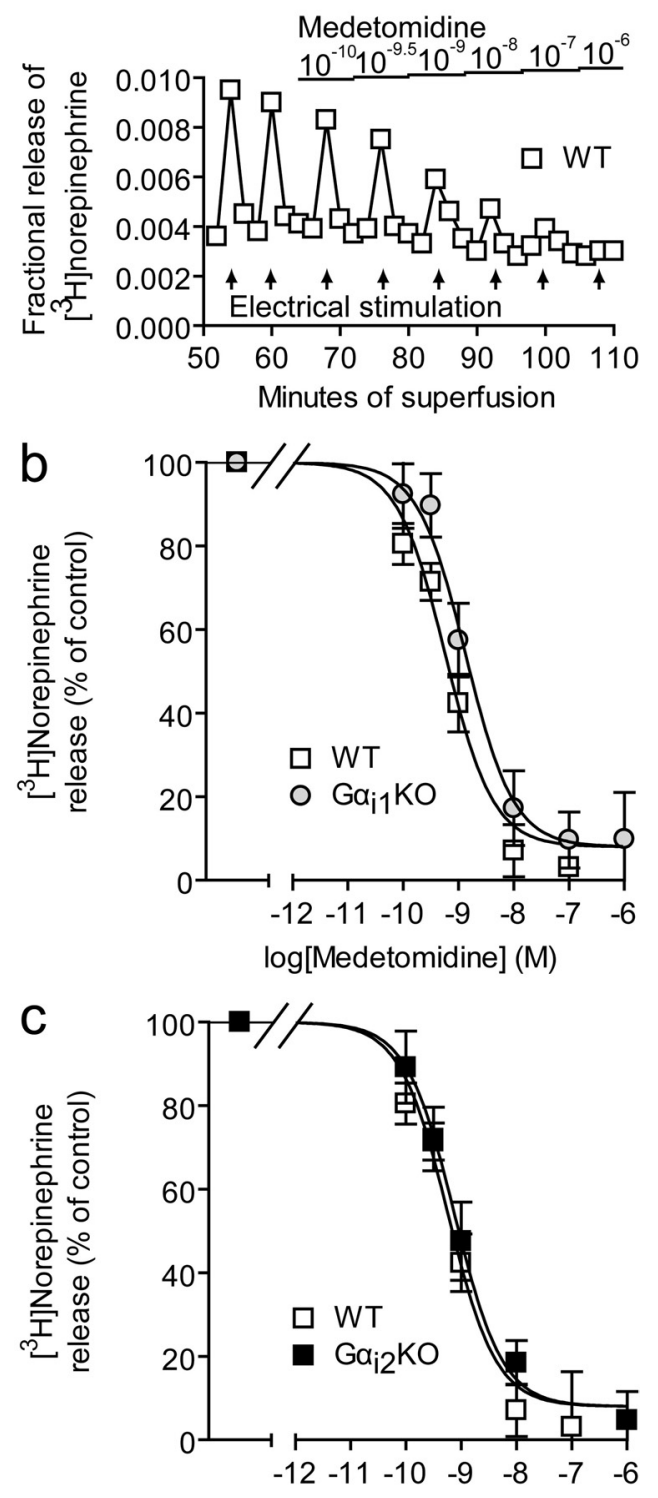

log[Medetomidine] (M)
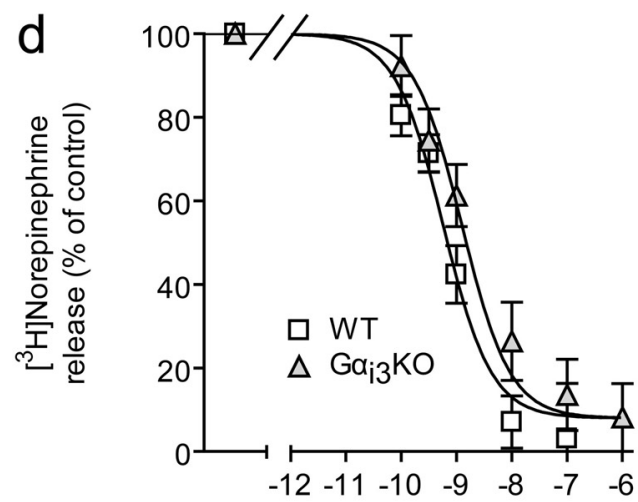

$\log [$ Medetomidine] (M)
TABLE 2

Inhibition of $\left[{ }^{3} \mathrm{H}\right]$ norepinephrine release from isolated mouse cardiac atria or prefrontal brain cortex slices by the $\alpha_{2}$-adrenoceptor agonist medetomidine

$\mathrm{pEC}_{50}$ values were determined from medetomidine concentration-response curves obtained from experiments using mouse cardiac atrial tissue or cortical brain slices. $\mathrm{pEC}_{50}$ values did not differ significantly between wild type and the indicated $\mathrm{G} \alpha_{\mathrm{i}}$ genotypes $(p>0.05)$

\begin{tabular}{lcccl}
\hline & \multicolumn{2}{c}{ Atria $\left(\mathrm{pEC}_{50} \pm\right.$ S.E.M. $)$} & \multicolumn{2}{c}{ Cortex $\left(\mathrm{pEC}_{50} \pm\right.$ S.E.M. $)$} \\
\hline Wild type & $9.29 \pm 0.18$ & $(n=5)$ & $9.16 \pm 0.11$ & $(n=12)$ \\
$\mathrm{G} \alpha_{i 1} \mathrm{KO}$ & $8.85 \pm 0.36$ & $(n=5)$ & $8.81 \pm 0.18$ & $(n=8)$ \\
$\mathrm{G} \alpha_{\mathrm{i} 2} \mathrm{KO}$ & $9.79 \pm 0.28$ & $(n=5)$ & $9.21 \pm 0.12$ & $(n=12)$ \\
$\mathrm{G} \alpha_{\mathrm{i} 3} \mathrm{KO}$ & $8.84 \pm 0.26$ & $(n=5)$ & $9.03 \pm 0.14$ & $(n=12)$ \\
\hline
\end{tabular}

to reduce dosing of inhalative anesthetics to induce sedation (Lakhlani et al., 1997). This "anesthetic sparing" effect may also be used therapeutically for patients to reduce the doses of general anesthetics (Maze et al., 2001). In wild-type mice, 50 or $100 \mu \mathrm{g} / \mathrm{kg}$ medetomidine caused a significant leftward shift of the concentration-response curve for isoflurane to induce loss of righting (Fig. 3, a and e). A similar shift to lower isoflurane concentrations was observed in mice deficient in $\mathrm{G} \alpha_{\mathrm{i} 1}$ or $\mathrm{G} \alpha_{\mathrm{i} 3}$ at $100 \mu \mathrm{g} / \mathrm{kg}$ but not at $50 \mu \mathrm{g} / \mathrm{kg} \mathrm{me}-$ detomidine (Fig. 3, b, d, and e). However, this effect was completely absent in $\mathrm{G \alpha}_{\mathrm{i} 2}$-deficient mice (Fig. 3, c and e), indicating that $\mathrm{G} \alpha_{\mathrm{i} 2}$ subunits are essential to mediate the anesthetic sparing effect of $\alpha_{2}$-agonists in a nonredundant manner.

Similar results were obtained for UK14,304, an $\alpha_{2}$-adrenceptor agonist that differs in its chemical structure from medetomidine (Fig. 4, a and b). The reduction in locomotor activity by the $\alpha_{2}$-agonist UK14,304 was significantly blunted in $\mathrm{G}_{\alpha_{2} 2}-\mathrm{KO}$ mice (Fig. $4 \mathrm{~b} ; * * p<0.01$ versus WT). Furthermore, UK14,304 caused a leftward shift of the isoflurane-mediated loss of righting reflex curves in WT mice and in animals lacking $\mathrm{G} \alpha_{\mathrm{i} 1}$ or $\mathrm{G} \alpha_{\mathrm{i} 3}$ but not in $\mathrm{G} \alpha_{\mathrm{i} 2}$-deficient mice (Fig. 4, c-f).

Role of $\mathbf{G} \alpha_{i 1}, G \alpha_{i 2}$, and $G \alpha_{i 3}$ Isoforms in the Antinociceptive Effect Mediated by $\alpha_{2}$-Adrenoceptor Activation. We determined whether $\mathrm{G} \alpha_{i 1}, \mathrm{G} \alpha_{i 2}$, or $\mathrm{G} \alpha_{i 3}$ proteins are required for the antinociceptive effect of medetomidine in the tail-flick assay (Lakhlani et al., 1997; Stone et al., 1997). In the absence of medetomidine, tail-flick latency times did not differ between $\mathrm{G} \alpha_{\mathrm{i}}$-deficient mouse strains compared with wild-type mice (Fig. 5a). After application of medetomidine (100 or $200 \mu \mathrm{g} / \mathrm{kg}$ i.p.), all genotype groups showed a significant and comparable antinociceptive effect as evidenced by a dose-dependent increase of the time until tail withdrawal (Fig. 5a).

Role of $\mathbf{G} \alpha_{i 1}, \mathbf{G} \alpha_{i 2}$, and $\mathbf{G} \alpha_{i 3}$ Proteins in Hypothermia Mediated by $\alpha_{2}$-Adrenoceptor Activation. At rest, body core temperature did not differ between wild-type mice or animals deficient in $\mathrm{G}_{\mathrm{i}}$ subunits (Fig. 5b). After administration of medetomidine, all groups showed a strong and dosedependent hypothermic effect as measured by an average

Fig. 1. Effect of the $\alpha_{2}$-adrenoceptor agonist medetomidine on $\left[{ }^{3} \mathrm{H}\right]$ norepinephrine release from brain cortex slices. a, tritium efflux- versus timecurves from brain cortex slices of $\mathrm{G}_{\mathrm{i} 1}-\mathrm{KO}$ mice. Cortex slices were stimulated with four rectangular electrical pulses at $100 \mathrm{~Hz}$ (2-ms pulse width; 80 $\mathrm{mA}$ ) applied at 8-min intervals. $\left[{ }^{3} \mathrm{H}\right]$ Norepinephrine release was inhibited by addition of medetomidine. $b$ to $d$, concentration-response curves for the inhibition of $\left[{ }^{3} \mathrm{H}\right]$ norepinephrine release by medetomidine. For ease of comparison, results from wild-type specimens (open squares) were reproduced in $\mathrm{b}$ to d. Data are means \pm S.E.M. from $n=8$ to 12 mice. 

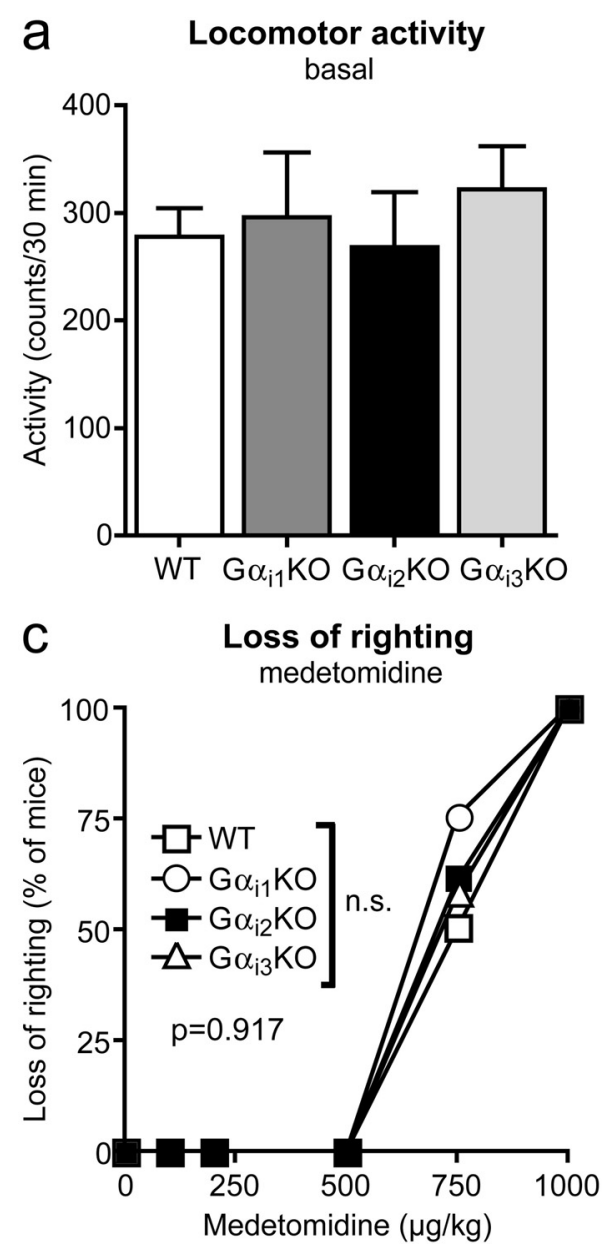
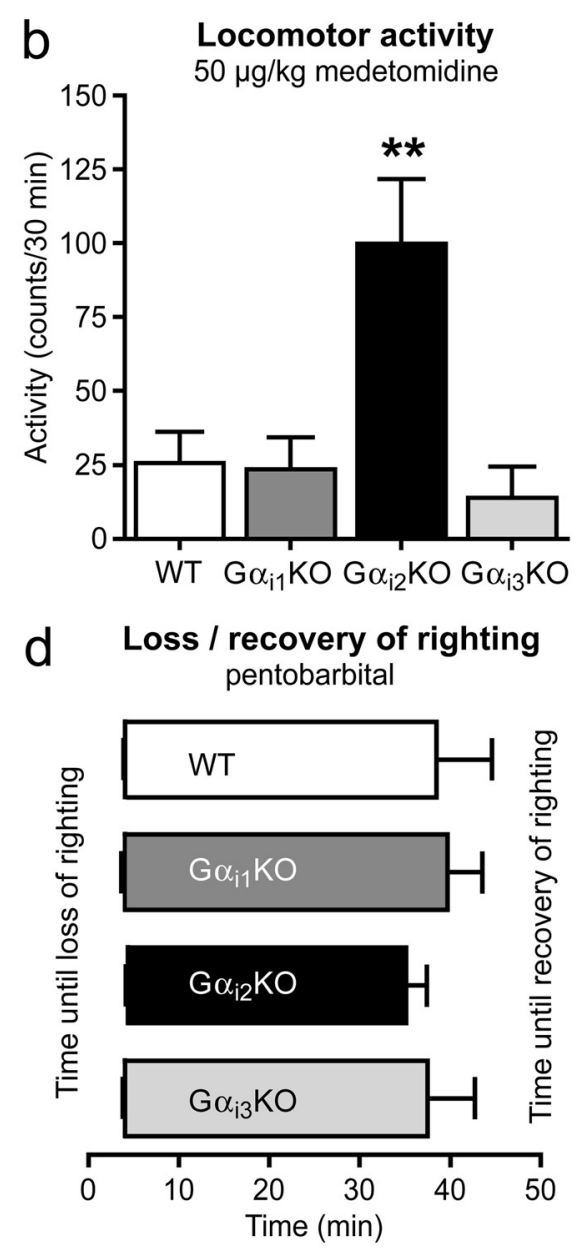

Fig. 2. Inhibition of locomotor activity and loss of righting reflex by medetomidine $(\mathrm{a}-\mathrm{c})$ or pentobarbital (d) in mice lacking $\mathrm{G} \alpha_{\mathrm{i}}$ isoforms. a, spontaneous locomotor activity as determined in an infrared photobeam cage system did not differ between genotype groups. b, medetomidine $(50 \mu \mathrm{g} / \mathrm{kg}$ ) reduced activity by $>90 \%$ in WT, $\mathrm{G} \alpha_{\mathrm{i} 1}-\mathrm{KO}$, or $\mathrm{G} \alpha_{\mathrm{i} 3}-\mathrm{KO}$ mice but to $37.2 \pm 8.1 \%$ in $\mathrm{G} \alpha_{\mathrm{i} 2}-\mathrm{KO}$ mice $(n=6-8 /$ genotype; $*, p<0.01$ versus WT). c, higher doses of medetomidine induced a strong sedative effect, i.e., loss of the righting reflex, in all genotype groups (percentage of mice that lost the righting reflex; $p>0.05$ versus WT). $d$, pentobarbital-induced loss of righting reflex. Time to present loss of righting after administration of $50 \mathrm{mg} / \mathrm{kg}$ i.p. pentobarbital (mean \pm S.E.M. represented by left margin of the horizontal bars) or time to recovery from loss of righting (mean \pm S.E.M. represented by right margin of horizontal bars) did not significantly differ between genotypes. Data are means \pm S.E.M. from $n=6$ mice/group ( $p>0.05$ versus WT). temperature decrease of $4.1 \pm 0.22^{\circ} \mathrm{C}$ after treatment with $200 \mu \mathrm{g} / \mathrm{kg}$ medetomidine. Again, no significant differences in the $\alpha_{2}$-agonist induced hypothermic effect were observed between the genotype groups (Fig. 5b).

Role of $\mathbf{G} \alpha_{i 1}, \mathbf{G} \alpha_{i 2}$, and $\mathbf{G} \alpha_{i 3}$ Isoforms in the Cardiovascular Effects of $\boldsymbol{\alpha}_{\mathbf{2}}$-Adrenoceptor Stimulation. Next, we analyzed the role of $\mathrm{G} \alpha_{\mathrm{i}}$ proteins downstream of the $\alpha_{2}$-adrenoceptor in cardiovascular function. It is interesting that basal heart rate and systolic or diastolic blood pressure as determined by microtip catheterization during isoflurane anesthesia did not differ between genotypes (Fig. 6). To assess the bradycardic and hypotensive effects of $\alpha_{2}$-adrenoceptor stimulation, medetomidine was infused intravenously at increasing doses (Fig. 6). In wild-type mice, medetomidine (at the maximal dose of $500 \mu \mathrm{g} / \mathrm{kg}$ ) lowered heart rate by $214 \pm$ $11 \mathrm{beats} / \mathrm{min}$. Systolic and diastolic blood pressure were decreased by $19.5 \pm 5.9$ and $20.0 \pm 5.4 \mathrm{~mm} \mathrm{Hg}$ by the $\alpha_{2}$ agonist, respectively (Fig. 6, b and c). Comparable bradycardic or hypotensive effects of medetomidine were recorded

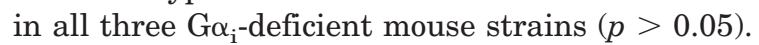

Expression of $\mathrm{G}_{\mathrm{i}}$ Proteins in the Locus Coeruleus or Sympathetic Ganglia. To determine the expression of $\mathrm{G} \alpha_{\mathrm{i}}$ isoforms in neurons involved in the tested pharmacological $\alpha_{2}$-agonist effects, $\mathrm{G} \alpha_{\mathrm{i}}$ mRNA levels were measured by quantitative real-time PCR in wild-type tissue specimens. For this purpose, the locus coeruleus was identified by tyrosine hydroxylase immunohistochemistry (Fig. 7a), and the area of the locus coeruleus was microdissected from adjacent cryostat sections. In these specimens, $\mathrm{G} \alpha_{\mathrm{i} 1}$ and $\mathrm{G} \alpha_{\mathrm{i} 2}$ subunits were both expressed at similar levels (Fig. 7c). In contrast, 4-fold lower amounts of $\mathrm{G}_{\alpha_{\mathrm{i} 3}}$ mRNA were detected in the microdissected locus coeruleus. Also in stellate ganglia (Fig. 7b), which contain sympathetic neurons innervating the heart and thoracic blood vessels, $\mathrm{G} \alpha_{\mathrm{i} 2}$ and $\mathrm{G} \alpha_{\mathrm{i} 1}$ were more abundantly expressed than $\mathrm{G}_{\mathrm{i} 3}$ (Fig. 7d).

\section{Discussion}

The diversity of $\mathrm{G}$ protein-coupled receptors and heterotrimeric $\mathrm{G}$ protein subunits translates into a wide variety of physiological and pharmacological effects that are propagated by different intracellular $\mathrm{G}$ protein-dependent effector mechanisms. However, the biological significance and potential subtype- or isoform-specific roles within receptor or G protein subfamilies has not been fully elucidated. In the present study, we have tested whether $\alpha_{2}$-adrenoceptors that are known to couple to $G_{i}$ proteins (the latter originally named for their ability to inhibit the activity of adenylyl cyclases) require specific $\mathrm{G} \alpha_{\mathrm{i}}$ isoforms for their physiological function in mouse models in vivo. It is interesting that inhibition of locomotor activity and the anesthetic sparing effect of low doses of the $\alpha_{2}$-adrenoceptor agonist medetomidine in the presence of isoflurane were blunted or absent in mice lacking $\mathrm{G \alpha}_{\mathrm{i} 2}$ (Figs. 2 and 3). In contrast, several other functions elicited by $\alpha_{2}$-adrenoceptor activation, including feedback inhibition of neurotransmitter release, bradycardia, 

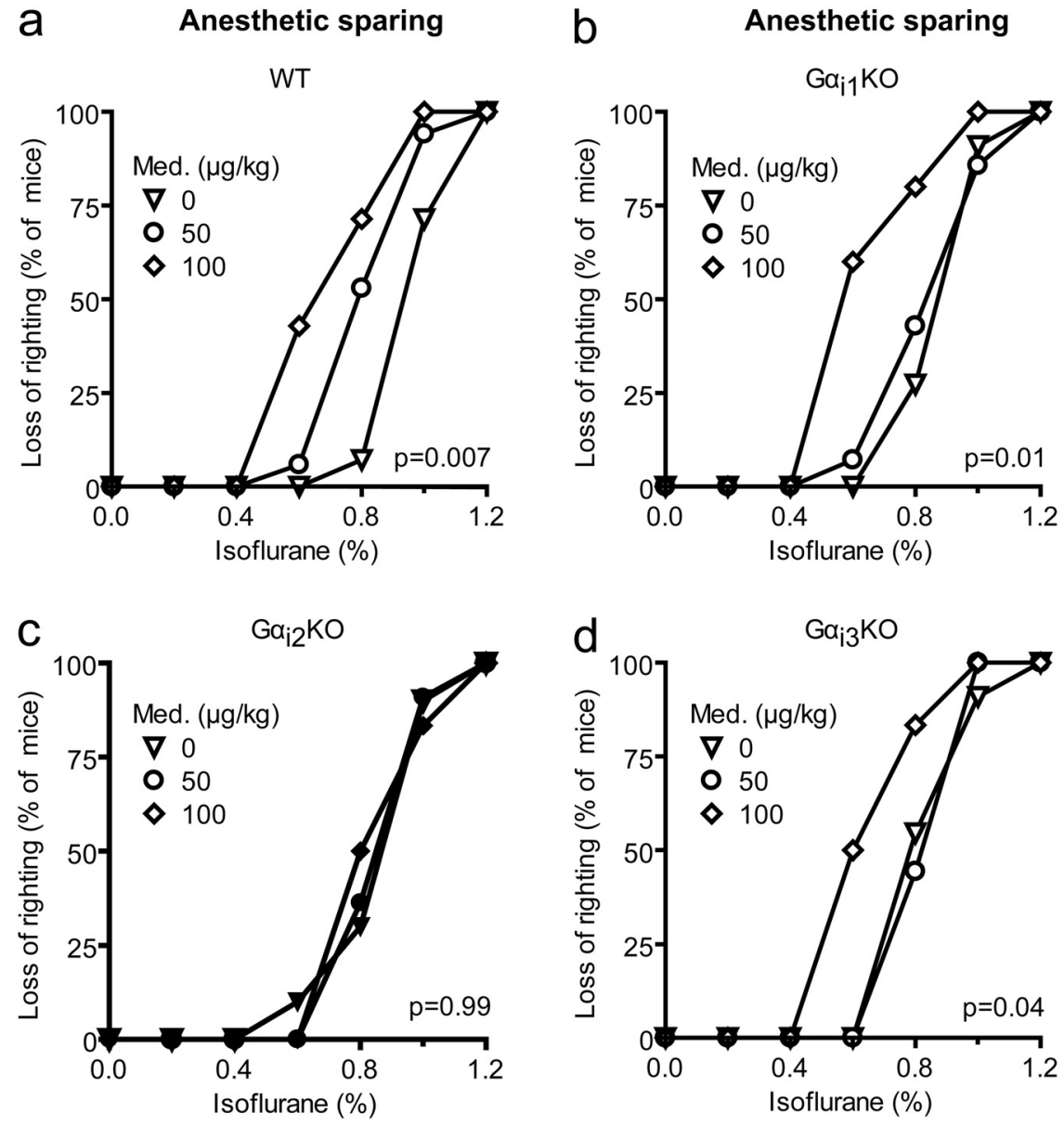

Fig. 3. Anesthetic sparing effect of $\alpha_{2}$-adrenoceptor activation in mice deficient in individual $\mathrm{G} \alpha_{\mathrm{i}}$ protein subunits. a to d, medetomidine was administered at doses that did not cause loss of the righting reflex (50 or $100 \mu \mathrm{g} / \mathrm{kg}$ i.p.) $30 \mathrm{~min}$ before exposure to increasing concentrations of isoflurane $(0-1.2 \mathrm{vol} \%$ in $\mathrm{O}_{2}$ ). Medetomidine caused a leftward shift of the isoflurane-mediated loss of righting reflex curves in WT (50 or $100 \mu \mathrm{g} / \mathrm{kg}$ ) mice and in animals lacking $\mathrm{G} \alpha_{\mathrm{i} 1}(100 \mu \mathrm{g} / \mathrm{kg})$ and $\mathrm{G}_{\alpha_{\mathrm{i} 3}}(100 \mu \mathrm{g} / \mathrm{kg})$ but not in $\mathrm{G} \alpha_{\text {in }}$-deficient mice ( $n=12$ mice/genotype). e, concentration of isoflurane required to induce loss of righting reflex in $50 \%$ of wild-type or $\mathrm{G}_{\mathrm{i}_{\mathrm{i}}}$-deficient mice in the absence ( 0 , control) or presence of medetomidine (50 and $100 \mu \mathrm{g} / \mathrm{kg}$ i.p.; *, $p<0.05$ versus control).

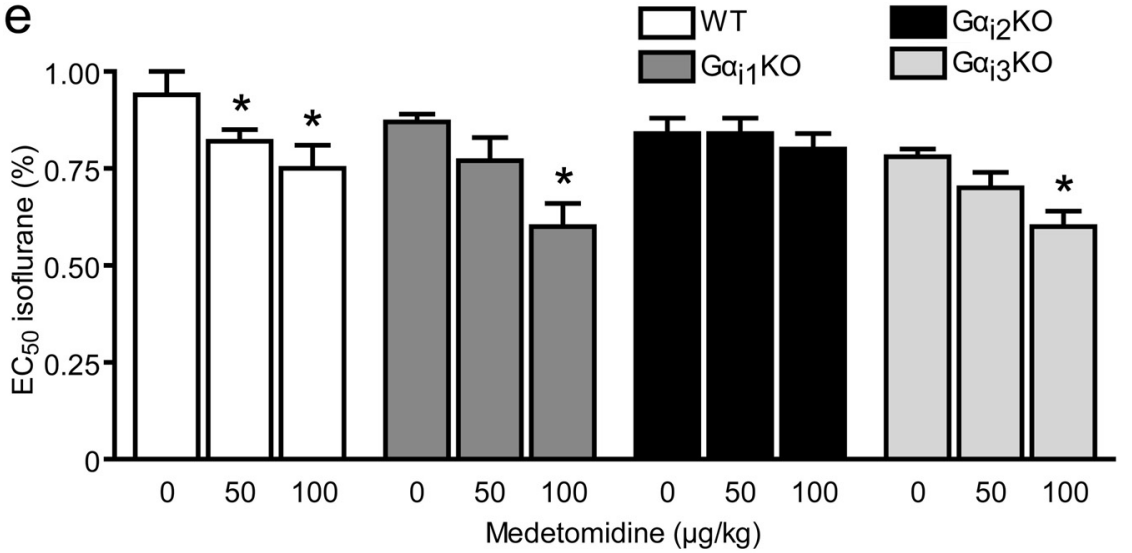

hypotension, induction of sleep, antinociception, and hypothermia, did not essentially require individual $\mathrm{G} \alpha_{\mathrm{i}}$ isoforms. Thus, functional redundancy of $\mathrm{G} \alpha_{i}$ isoforms may predominate over specificity to activate distinct intracellular $\alpha_{2}$-receptor/G $\alpha_{\mathrm{i}}$-driven signaling pathways in vivo. In this regard, previous phenotypic analysis of $\mathrm{G} \alpha_{i}$ knockout mouse strains revealed further shared as well as gene-specific functions of $\mathrm{G} \alpha_{i}$ proteins in vivo. For example, mice lacking both $\mathrm{G} \alpha_{i 2}$ and $\mathrm{G}_{\mathrm{i} 3}$ are growth retarded and die in utero, clearly demonstrating functional redundancy between these two isoforms during embryonic development (Gohla et al., 2007). In contrast, the specific roles of $\mathrm{G}_{\alpha_{12}}$ and $\mathrm{G}_{\alpha_{\mathrm{i} 3}}$ in alveolar macrophage function (Skokowa et al., 2005) and antiautophagic action (Gohla et al., 2007), respectively, cannot be compensated by each other.

$\alpha_{2}$-Adrenoceptors are members of the family of adrenergic receptors that mediate the biological functions of the endogenous catecholamines epinephrine and norepinephrine (Hein, 2001; Gilsbach and Hein, 2008; Gilsbach et al., 2009). To date, nine different adrenergic receptor subtypes have been cloned and arranged into three receptor groups, including $\alpha_{1 \mathrm{A,B}, \mathrm{D}}, \alpha_{2 \mathrm{A,B}, \mathrm{C}}$, and $\beta_{1,2,3}$ (Bylund et al., 1994). For the subfamily of $\alpha_{2}$-adrenoceptors, mouse models with targeted deletions of the individual subtypes have greatly advanced our understanding of the physiological role and the therapeutic potential of these receptors (for recent review, see 

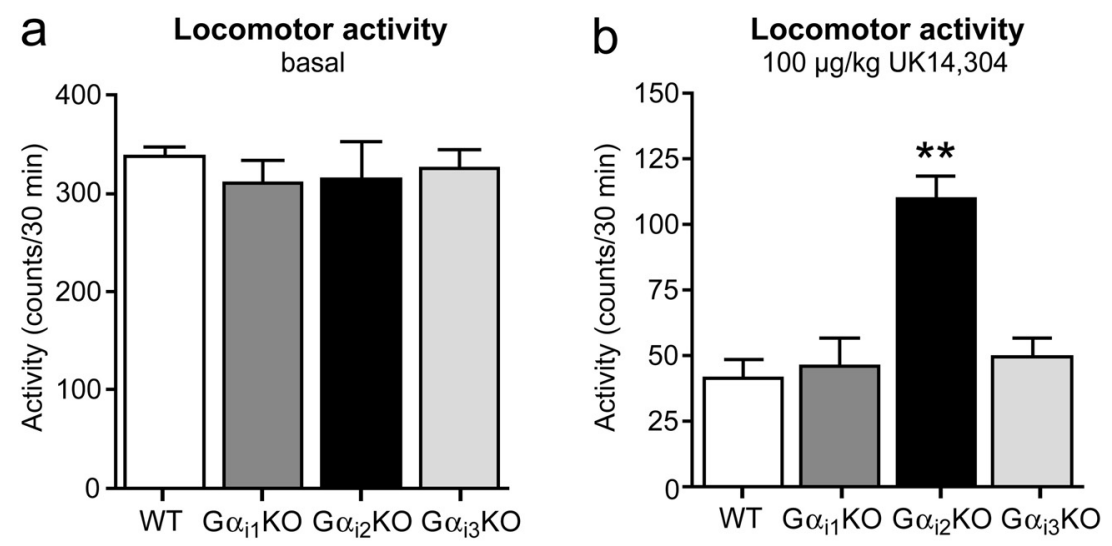
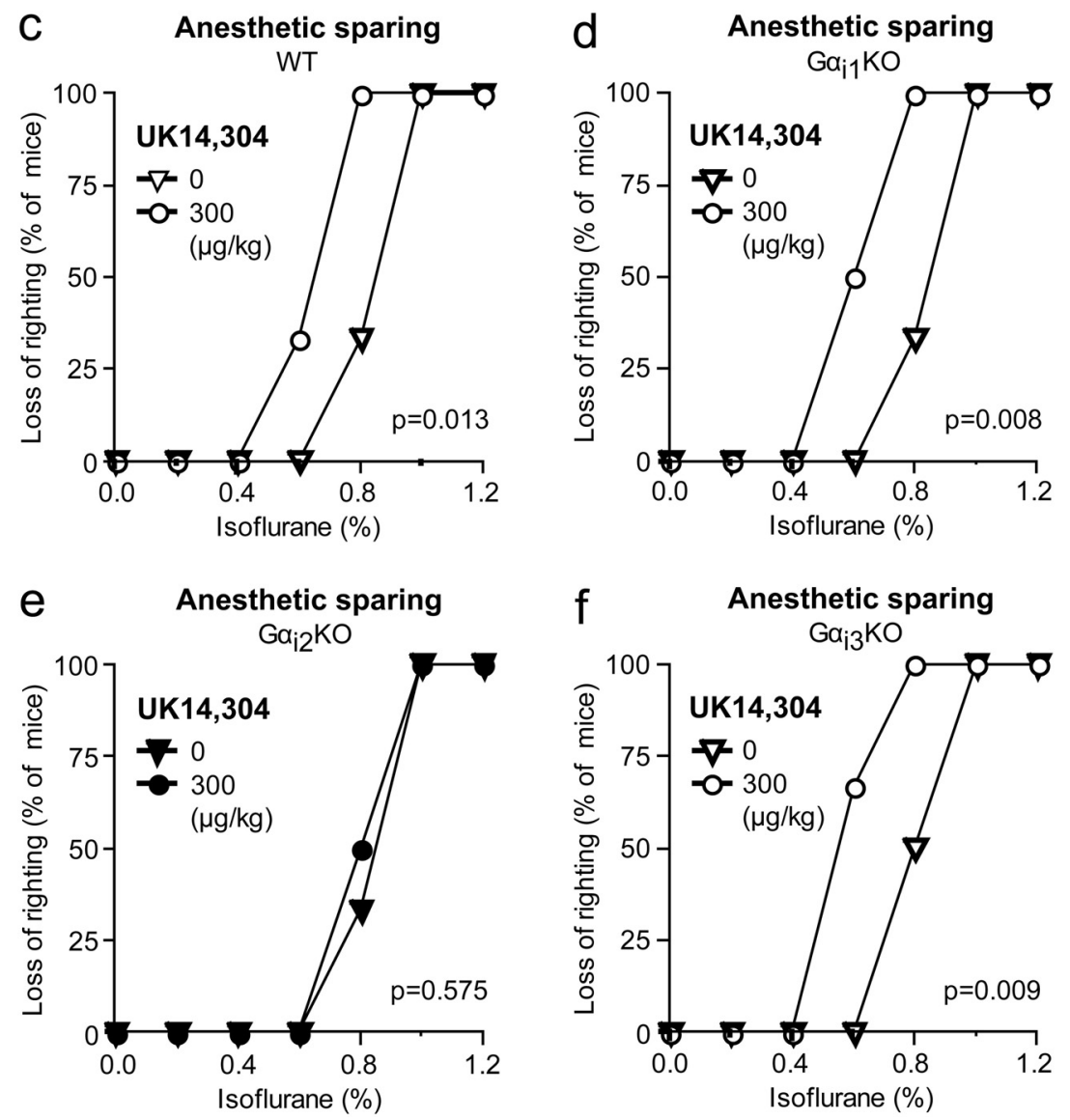

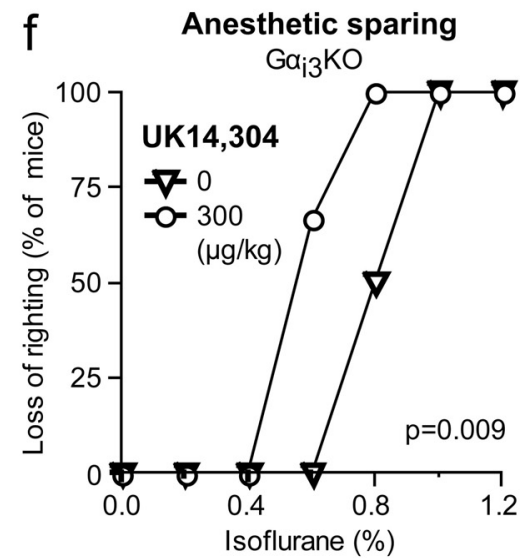

Fig. 4. Inhibition of locomotor activity and anesthetic sparing effect of the $\alpha_{2}$-adrenoceptor agonist UK14,304. a, spontaneous locomotor activity as determined in an infrared photobeam cage system did not differ between genotype groups. b, UK14,304 (100 $\mu \mathrm{g} / \mathrm{kg})$-mediated reduction in activity was significantly blunted in $\mathrm{G}_{\alpha_{2} 2}-\mathrm{KO}$ mice ( $n=8-12 /$ measurements per genotype; $* *, p<$ 0.01 versus WT). $\mathrm{c}$ to $\mathrm{f}$, UK14,304 was administered at $300 \mu \mathrm{g} / \mathrm{kg}$ i.p. $30 \mathrm{~min}$ before exposure to increasing concentrations of isoflurane $\left(0-1.2\right.$ vol\% in $\left.\mathrm{O}_{2}\right)$. UK14,304 caused a leftward shift of the isofluranemediated loss of righting reflex curves in WT mice and in animals lacking $\mathrm{G} \alpha_{\mathrm{i} 1}$ or $\mathrm{G} \alpha_{\mathrm{i} 3}$ but not in $\mathrm{G} \alpha_{\mathrm{i} 2}$-deficient mice ( $n=6$ mice/genotype, log rank test).
Gilsbach and Hein, 2008). In this study, the $\alpha_{2}$-agonists medetomidine and UK14,304 were used to activate $\alpha_{2}$-mediated signaling pathways in vivo. Medetomidine and its active enantiomer dexmedetomidine is a partial agonist with similar potency at all three $\alpha_{2}$-adrenoceptor subtypes and approximately 1000-fold selectivity for $\alpha_{2}$ - versus $\alpha_{1}$-adrenoceptors (Jasper et al., 1998). Activation of $\alpha_{2 \mathrm{~A}}$-receptors could be linked with bradycardia and hypotension (MacMillan et al., 1996), sedation (Lakhlani et al., 1997; Gilsbach et al., 2009), and consolidation of working memory (Wang et al., 2007). Hypothermia and antinociception induced by $\alpha_{2}$-agonists depend primarily on functional $\alpha_{2 \mathrm{~A}}$-adrenoceptors (Stone et al., 1997; Gilsbach et al., 2009), but other subtypes may also contribute to these pharmacological effects under certain conditions (Sallinen et al., 1997; Fairbanks et al., 2009). $\alpha_{2 \mathrm{~B}}$-receptors counteracted the hypotensive effect of $\alpha_{2 \mathrm{~A}}$-receptors (Link et al., 1996) and were essential for placenta vascular development (Philipp et al., 2002). $\alpha_{2 \mathrm{C}}$-Receptors were identified as feedback regulators of adrenal catecholamine release (Brede et al., 2002). Thus, most of the pharmacological functions tested in the present study were mediated by the $\alpha_{2 \mathrm{~A}}$-adrenoceptor subtype, with one exception: in vitro experiments have demonstrated that all three $\alpha_{2}$-adrenoceptor subtypes may participate in feedback inhibition of neurotransmitter release from adrenergic neurons (Trendelenburg et al., 2003). However, despite expression of all the $\alpha_{2}$-adrenoceptor subtypes in postganglionic sympathetic neurons (Trendelenburg et al., 2003), functional specificity could be demonstrated. $\alpha_{2 \mathrm{~A}}$-Adrenoceptors inhibited norepinephrine release from isolated mouse atria primarily at high 

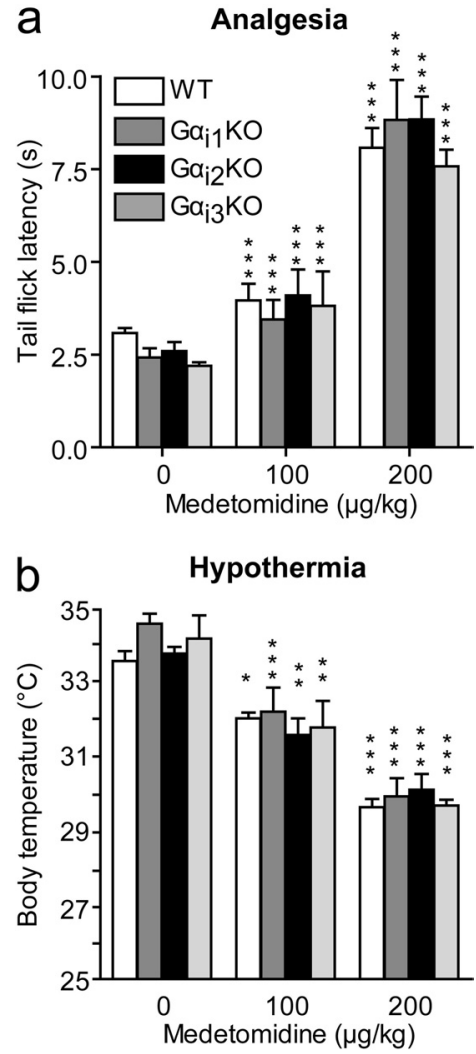

Fig. 5. Antinociceptive and hypothermic effects of $\alpha_{2}$-adrenoceptor stimulation in mice lacking $\mathrm{G} \alpha_{i}$ protein isoforms. a, pain threshold was assessed by determining the tail-flick latency. Administration of medetomidine (100 or $200 \mu \mathrm{g} / \mathrm{kg}$ i.p.) prolonged the tail-flick latency in all groups, although this effect did not differ significantly between genotypes ( $*, p<0.001$ versus respective saline group; $n=8 /$ genotype). $\mathrm{b}$, body core temperature was determined during isoflurane anesthesia by a rectal probe. Administration of medetomidine (100 or $200 \mu \mathrm{g} / \mathrm{kg}$ i.p.) caused a reduction in body temperature in all genotype groups $(*, p<0.05 ; * *, p<$ 0.01 ; and $* *, p<0.001$ versus basal values in the absence of medetomidine; $n=12$ /genotype).

action potential frequencies, whereas $\alpha_{2 \mathrm{C}}$-adrenoceptors operated at lower stimulation frequencies (Hein et al., 1999). In the present study, short trains of electrical stimulation at high frequency ( $100 \mathrm{~Hz}$; "pseudo-one pulse condition") were used to favor $\alpha_{2 \mathrm{~A}}$-adrenoceptor action.

In contrast to the functional specificity observed with individual $\alpha_{2}$-adrenoceptor subtypes expressed in the same neuron, we did not find any specificity for $\mathrm{G}_{\mathrm{i}}$ isoforms in terms of inhibition of neurotransmitter release from prefrontal cortex brain slices or cardiac atria in this study. To test whether this lack of specificity was associated with a coexpression of $\mathrm{G}_{\mathrm{i}}$ isoforms (and hence potential functional redundancy) in the same neurons, we determined the mRNA expression of $\mathrm{G} \alpha_{\mathrm{i}}$ isoforms in microdissected locus coeruleus and stellate ganglia. Noradrenergic neurons from the locus coeruleus project to various regions in the central nervous system, including the prefrontal cortex. In addition, inhibition of the activity of locus coeruleus neurons has been implicated in the sedative and sleep-inducing effects of $\alpha_{2}$ adrenoceptor agonists (Mizobe et al., 1996). It is interesting that although $\mathrm{G} \alpha_{\mathrm{i} 1}$ and $\mathrm{G} \alpha_{\mathrm{i} 2}$ subunits predominated in their expression levels over $\mathrm{G \alpha}_{\mathrm{i} 3}$ in this brain nucleus (Fig. 7), genetic deletion of any of the three $\mathrm{G} \alpha_{i}$ subunits failed to affect feedback inhibition of $\left[{ }^{3} \mathrm{H}\right]$ norepinephrine release from
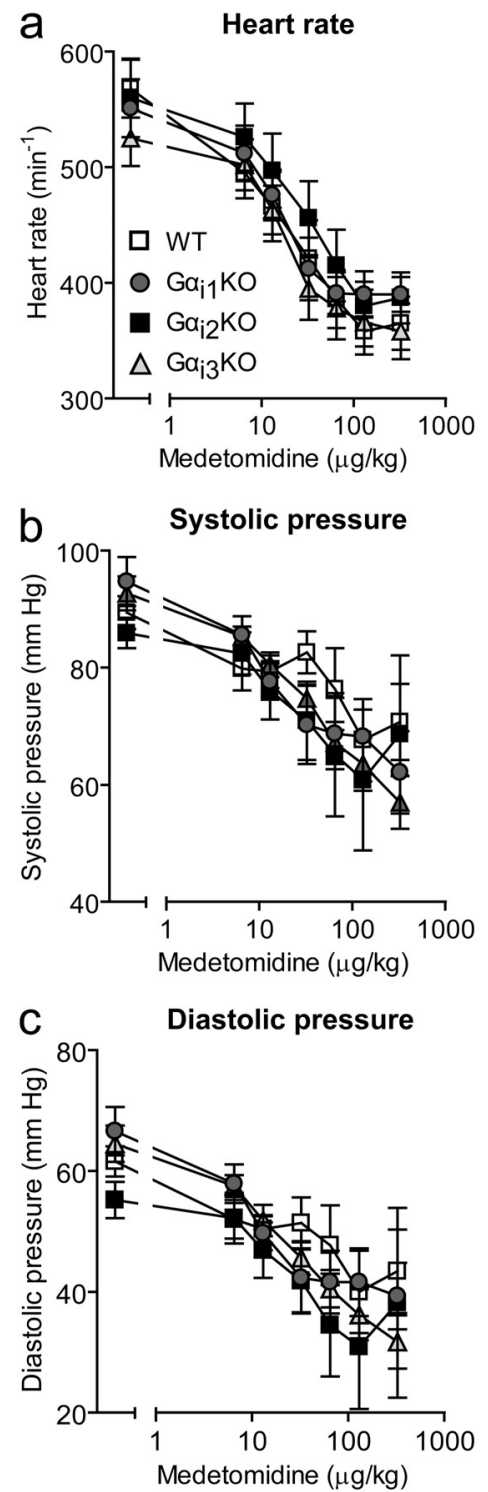

Fig. 6. Hemodynamic effects of $\alpha_{2}$-adrenoceptor stimulation in mice deficient in $\mathrm{G} \alpha_{i}$ protein isoforms. Heart rate (a) and aortic systolic (b) and diastolic (c) pressures were determined during isoflurane anesthesia by Millar microtip catheterization. Medetomidine elicited similar bradycardic (a) and hypotensive (b and c) effects in mice from all genotype groups ( $n=6-8$ mice/group; $p>0.05$ versus WT).

isolated brain cortex (Fig. 1). In contrast, two tests to assess the sedative effects of high and low doses of $\alpha_{2}$-adrenoceptor agonists differed in their requirement for $\mathrm{G}_{\mathrm{i}}$ subunits. At high doses of medetomidine, ablation of expression of single $\mathrm{G} \alpha_{\mathrm{i}}$ isoforms did not affect the agonist-induced loss of righting (Fig. 2c). In contrast, the anesthetic sparing effect of medetomidine given at 5- to 10 -fold lower doses was specifically lost in mice with targeted deletion of the $\mathrm{G} \alpha_{\mathrm{i} 2}$ gene (Fig. $3 c$ ). This observation is interesting given the fact that $\mathrm{G} \alpha{ }_{\mathrm{i} 3}$ is up-regulated in various tissues from $\mathrm{G \alpha}_{\mathrm{i} 2}$-deficient mice ( $\mathrm{Ru}$ dolph et al., 1995; Gohla et al., 2007) by currently unknown mechanism(s). The present findings indicate that $\alpha_{2 \mathrm{~A}}$-adrenoceptors, especially at low levels of receptor activation, may couple specifically to $\mathrm{G \alpha}_{\mathrm{i} 2}$-containing heterotrimeric $\mathrm{G}_{\mathrm{i}}$ proteins. However, at higher agonist concentrations, specificity of receptor- $G_{i}$ protein coupling may be lost, indicating functional redundancy among the $\mathrm{G} \alpha_{\mathrm{i}}$ isoforms expressed. Alter- 

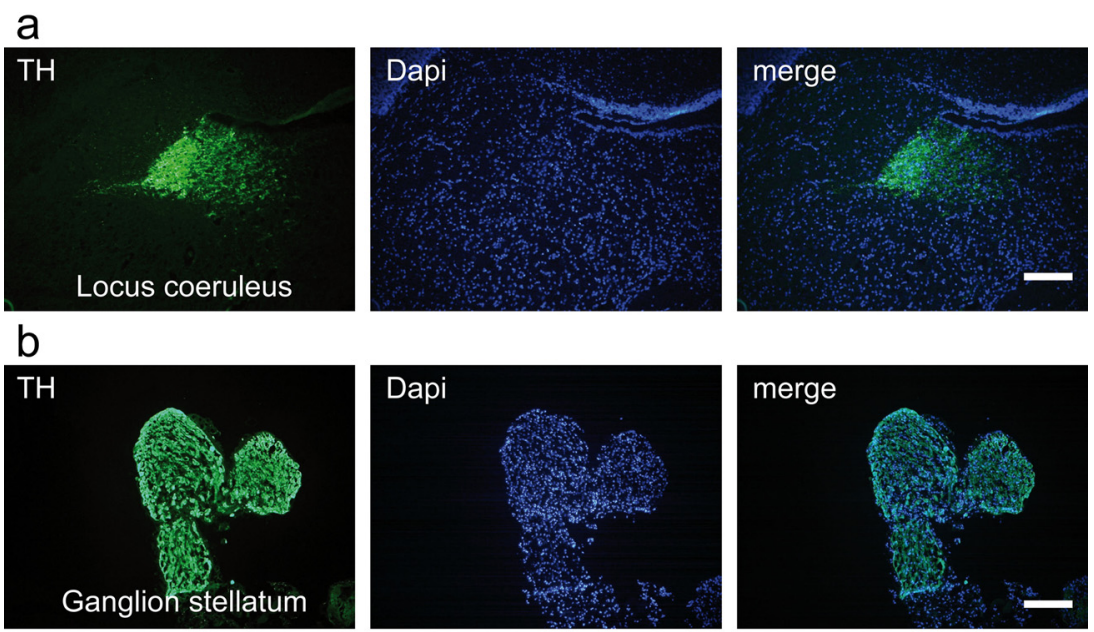

C

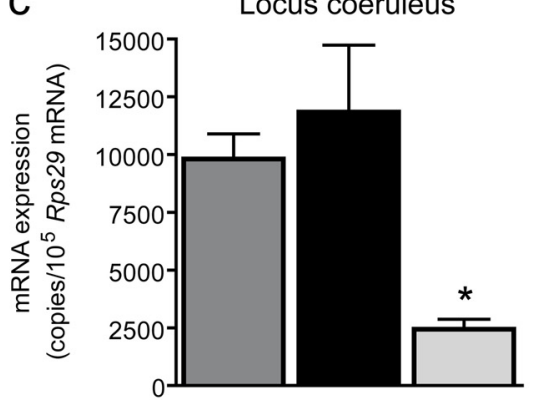

d
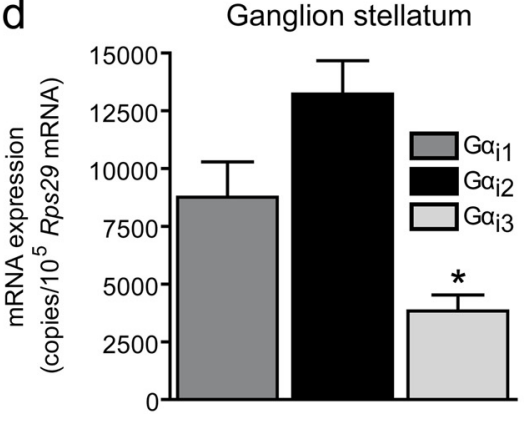

Fig. 7. Expression of $\mathrm{G}_{\alpha_{\mathrm{i}}}$ isoform mRNA in locus coeruleus and stellate ganglia from wild-type mice. $a$ and $b$, identification of the locus coeruleus in cryostat sections through wild-type mouse brain (a) or sympathetic ganglion stellata (b) by anti-tyrosine hydroxylase immunostaining (green fluorescence). Nuclei were identified by blue 4',6-diamidino-2-phenylindole (Dapi) fluorescence. Right, overlay of tyrosine hydroxylase and Dapi signals. Scale bars, $200 \mu \mathrm{m}$ (a and b). c, quantification of $\mathrm{G} \alpha_{i}$ isoform mRNA in microdissected locus coeruleus or total stellate ganglia specimens by quantitative reverse transcription-PCR (*, $p<0.05$ versus $\left.\mathrm{G}_{\alpha_{i 1}}\right)$. natively, agonist-induced loss of righting and anesthetic sparing may be mediated by separate neurons and/or brain regions differing in their relative expression of $\mathrm{G} \alpha_{\mathrm{i}}$ isoforms. Indeed, recent data suggest that in addition to their action in the locus coeruleus, $\alpha_{2}$-adrenoceptor agonists may activate an endogenous sleep-promoting pathway (Nelson et al., 2002; $\mathrm{Lu}$ et al., 2008). Transgenic rescue experiments expressing $\alpha_{2 \mathrm{~A}}$-adrenoceptors under control of the dopamine $\beta$-hydroxylase promoter have demonstrated that only few functions of $\alpha_{2}$-agonists were mediated by $\alpha_{2}$-receptors in adrenergic neurons, including inhibition of norepinephrine release and inhibition of locomotor activity (Gilsbach et al., 2009). Future experiments using neuron-specific gene targeting strategies will be required to determine whether sleep and anesthetic sparing have different neuronal substrates. Furthermore, electrophysiological experiments in tissue slices from selected brain regions will be essential to demonstrate direct coupling of $\alpha_{2 \mathrm{~A}}$-adrenoceptors and $\mathrm{G} \alpha_{\mathrm{i} 2}$ proteins.

In contrast to inhibition of locomotor activity and anesthetic sparing, we did not identify any other pharmacological effect of $\alpha_{2}$-adrenoceptor activation that specifically required one $\mathrm{G} \alpha_{\mathrm{i}}$ protein isoform. This may be due to a functional redundancy of $\mathrm{G}_{\mathrm{i}}$ subunits as discussed above or due to involvement of other pertussis-sensitive $\mathrm{G} \alpha$ subunits in these effects, most notably the $\mathrm{G} \alpha_{\mathrm{o}}$ proteins that are highly abundant in the central nervous system (Nürnberg, 2004). However, mice deficient in $\mathrm{G} \alpha_{\mathrm{o}}$ could not be included in the present study, because constitutive deletion of $\mathrm{G} \alpha_{\mathrm{o}}$ proteins already results in postnatal lethality and multiple neurological deficits (Jiang et al., 1998). It is interesting that $\mathrm{G} \alpha_{\mathrm{o}}$ has been implicated as the primary signaling element coupling $\alpha_{2}$-adrenoceptors to $\mathrm{N}$-type calcium channels in sympathetic neurons (Jeong and Ikeda, 2000a,b). Moreover, in rat neu- rons expressing a $\mathrm{G} \alpha_{\mathrm{o}}$ subunit resistant to pertussis toxin and regulators of $\mathrm{G}$ protein signaling proteins, norepinephrine-induced calcium current inhibition was shifted to lower concentrations (Jeong and Ikeda, 2000a,b). Thus, neuron type-specific and/or inducible deletion of the $\mathrm{G} \alpha_{\mathrm{o}}$ gene will be required to test the functional significance of $G \alpha_{i}$ versus $G \alpha_{o}$ proteins in $\alpha_{2}$-adrenoceptor function in the future.

The present study demonstrates for the first time that inhibition of locomotor activity and anesthetic sparing induced by $\alpha_{2 \mathrm{~A}}$-adrenoceptor activation specifically requires signaling via the $\mathrm{G} \alpha_{\mathrm{i} 2}$ isoform of heterotrimeric $\mathrm{G}_{\mathrm{i}}$ proteins.

\section{References}

Altman JD, Trendelenburg AU, MacMillan L, Bernstein D, Limbird L, Starke K, Kobilka BK, and Hein L (1999) Abnormal regulation of the sympathetic nervous system in $\alpha_{2 \mathrm{~A}}$-adrenergic receptor knockout mice. Mol Pharmacol 56:154-161.

Brede M, Wiesmann F, Jahns R, Hadamek K, Arnolt C, Neubauer S, Lohse MJ, and Hein L (2002) Feedback inhibition of catecholamine release by two different $\alpha_{2}$-adrenoceptor subtypes prevents progression of heart failure. Circulation 106: 2491-2496.

Bylund DB, Eikenberg DC, Hieble JP, Langer SZ, Lefkowitz RJ, Minneman KP, Molinoff PB, Ruffolo RR Jr, and Trendelenburg U (1994) International Union of Pharmacology nomenclature of adrenoceptors. Pharmacol Rev 46:121-136.

Fairbanks CA, Stone LS, and Wilcox GL (2009) Pharmacological profiles of $\alpha_{2}$ adrenergic receptor agonists identified using genetically altered mice and isobolographic analysis. Pharmacol Ther 123:224-238.

Gerhardt MA and Neubig RR (1991) Multiple Gi protein subtypes regulate a single effector mechanism. Mol Pharmacol 40:707-711.

Gibson SK and Gilman AG (2006) Gialpha and Gbeta subunits both define selectivity of $\mathrm{G}$ protein activation by $\alpha_{2}$-adrenergic receptors. Proc Natl Acad Sci USA 103:212-217.

Gilman AG (1987) G proteins: transducers of receptor-generated signals. Annu Rev Biochem 56:615-649.

Gilsbach R, Brede M, Beetz N, Moura E, Muthig V, Gerstner C, Barreto F, Neubauer S, Vieira-Coelho MA, and Hein L (2007) Heterozygous $\alpha_{2 \mathrm{C}}$-adrenoceptor-deficient mice develop heart failure after transverse aortic constriction. Cardiovasc Res 75:728-737.

Gilsbach R and Hein L (2008) Presynaptic metabotropic receptors for acetylcholine and adrenaline/noradrenaline. Handb Exp Pharmacol 184:261-288.

Gilsbach R, Röser C, Beetz N, Brede M, Hadamek K, Haubold M, Leemhuis J, Philipp M, Schneider J, Urbanski M, et al. (2009) Genetic dissection of $\alpha_{2^{-}}$ 
adrenoceptor functions in adrenergic versus non-adrenergic cells. Mol Pharmacol 75:1160-1170

Gohla A, Klement K, Piekorz RP, Pexa K, vom Dahl S, Spicher K, Dreval V, Haussinger D, Birnbaumer L, and Nürnberg B (2007) An obligatory requirement for the heterotrimeric $\mathrm{G}$ protein $\mathrm{G}_{\mathrm{i} 3}$ in the antiautophagic action of insulin in the liver. Proc Natl Acad Sci U S A 104:3003-3008.

Hein L (2001) Transgenic models of $\alpha_{2}$-adrenergic receptor subtype function. Rev Physiol Biochem Pharmacol 142:161-185.

Hein L, Altman JD, and Kobilka BK (1999) Two functionally distinct $\alpha_{2}$-adrenergic receptors regulate sympathetic neurotransmission. Nature 402:181-184.

Jasper JR, Lesnick JD, Chang LK, Yamanishi SS, Chang TK, Hsu SA, Daunt DA, Bonhaus DW, and Eglen RM (1998) Ligand efficacy and potency at recombinant $\alpha_{2}$ adrenergic receptors: agonist-mediated $\left[{ }^{35} \mathrm{~S}\right] \mathrm{GTP} \gamma \mathrm{S}$ binding. Biochem Pharmacol 55:1035-1043.

Jeong SW and Ikeda SR (2000a) Effect of G protein heterotrimer composition on coupling of neurotransmitter receptors to $\mathrm{N}$-type $\mathrm{Ca}^{2+}$ channel modulation in sympathetic neurons. Proc Natl Acad Sci U S A 97:907-912.

Jeong SW and Ikeda SR (2000b) Endogenous regulator of G-protein signaling proteins modify N-type calcium channel modulation in rat sympathetic neurons. $J$ Neurosci 20:4489-4496.

Jiang M, Gold MS, Boulay G, Spicher K, Peyton M, Brabet P, Srinivasan Y, Rudolph U, Ellison G, and Birnbaumer L (1998) Multiple neurological abnormalities in mice deficient in the $\mathrm{G}$ protein $\mathrm{G}_{\mathrm{o}}$. Proc Natl Acad Sci U S A 95:3269-3274.

Jiang M, Spicher K, Boulay G, Martín-Requero A, Dye CA, Rudolph U, and Birnbaumer L (2002) Mouse gene knockout and knockin strategies in application to alpha subunits of Gi/Go family of G proteins. Methods Enzymol 344:277-298.

Lakhlani PP, MacMillan LB, Guo TZ, McCool BA, Lovinger DM, Maze M, and Limbird LE (1997) Substitution of a mutant $\alpha_{2 \mathrm{~A}}$-adrenergic receptor via "hit and run" gene targeting reveals the role of this subtype in sedative, analgesic, and anesthetic-sparing responses in vivo. Proc Natl Acad Sci U S A 94:9950-9955.

Link RE, Desai K, Hein L, Stevens ME, Chruscinski A, Bernstein D, Barsh GS, and Kobilka BK (1996) Cardiovascular regulation in mice lacking $\alpha_{2}$-adrenergic receptor subtypes b and c. Science 273:803-805.

Lu J, Nelson LE, Franks N, Maze M, Chamberlin NL, and Saper CB (2008) Role of endogenous sleep-wake and analgesic systems in anesthesia. J Comp Neurol 508:648-662.

MacMillan LB, Hein L, Smith MS, Piascik MT, and Limbird LE (1996) Central hypotensive effects of the $\alpha_{2}$-adrenergic receptor subtype. Science 273:801-803.

Maze M, Scarfini C, and Cavaliere F (2001) New agents for sedation in the intensive care unit. Crit Care Clin 17:881-897.

Mizobe T, Maghsoudi K, Sitwala K, Tianzhi G, Ou J, and Maze M (1996) Antisense technology reveals the $\alpha_{2 A}$ adrenoceptor to be the subtype mediating the hypnotic response to the highly selective agonist, dexmedetomidine, in the locus coeruleus of the rat. J Clin Invest 98:1076-1080.

Morris AJ and Malbon CC (1999) Physiological regulation of G protein-linked signaling. Physiol Rev 79:1373-1430.

Nelson LE, Guo TZ, Lu J, Saper CB, Franks NP, and Maze M (2002) The sedative component of anesthesia is mediated by $\mathrm{GABA}_{\mathrm{A}}$ receptors in an endogenous sleep pathway. Nat Neurosci 5:979-984.

Nürnberg B (2004) Classification and functional properties of G $\alpha$ subunits, in The
Nature Reviews Drug Discovery GPCR Questionnaire Participants. The state of GPCR research in 2004. Nat Rev Drug Discov 575:577-626.

Nürnberg B, Gudermann T, and Schultz G (1995) Receptors and G proteins as primary components of transmembrane signal transduction. Part 2. G proteins: structure and function. $\mathrm{J} \mathrm{Mol} \mathrm{Med} \mathrm{73:123-132.}$

Offermanns S (2003) G-proteins as transducers in transmembrane signalling. Prog Biophys Mol Biol 83:101-130.

Paxinos G and Franklin KBJ (2001) The Mouse Brain in Stereotaxic Coordinates Academic Press, NY

Philipp M, Brede ME, Hadamek K, Gessler M, Lohse MJ, and Hein L (2002) Placental $\alpha_{2}$-adrenoceptors control vascular development at the interface between mother and embryo. Nat Genet 31:311-315.

Pineda VV, Athos JI, Wang H, Celver J, Ippolito D, Boulay G, Birnbaumer L, and Storm DR (2004) Removal of Gi $\alpha_{1}$ constraints on adenylyl cyclase in the hippocampus enhances LTP and impairs memory formation. Neuron 41:153-163.

Rudolph U, Finegold MJ, Rich SS, Harriman GR, Srinivasan Y, Brabet P, Boulay G, Bradley A, and Birnbaumer L (1995) Ulcerative colitis and adenocarcinoma of the colon in Goi2-deficient mice. Nat Genet 10:143-150.

Sallinen J, Link RE, Haapalinna A, Viitamaa T, Kulatunga M, Sjöholm B, Mac donald E, Pelto-Huikko M, Leino T, Barsh GS, et al. (1997) Genetic alteration of $\alpha_{2 \mathrm{C}}$-adrenoceptor expression in mice: influence on locomotor, hypothermic, and neurochemical effects of dexmedetomidine, a subtype-nonselective $\alpha_{2}$-adrenoceptor agonist. Mol Pharmacol 51:36-46.

Skokowa J, Ali SR, Felda O, Kumar V, Konrad S, Shushakova N, Schmidt RE Piekorz RP, Nürnberg B, Spicher K, et al. (2001) Macrophages induce the inflammatory response in the pulmonary Arthus reaction through $\mathrm{G}$ alpha i2 activation that controls C5aR and Fc receptor cooperation. J Immunol 174:3041-3050.

Smrcka AV (2008) G protein betagamma subunits: central mediators of G proteincoupled receptor signaling. Cell Mol Life Sci 65:2191-2214.

Stone LS, MacMillan LB, Kitto KF, Limbird LE, and Wilcox GL (1997) The $\alpha_{2}$ adrenergic receptor subtype mediates spinal analgesia evoked by $\alpha_{2}$ agonists and is necessary for spinal adrenergic-opioid synergy. J Neurosci 17:7157-7165.

Trendelenburg AU, Klebroff W, Hein L, and Starke K (2001) A study of presynaptic $\alpha_{2}$-autoreceptors in $\alpha_{2 \mathrm{~A} / \mathrm{D}^{-}}, \alpha_{2 \mathrm{~B}^{-}}$and $\alpha_{2 \mathrm{C}^{-}}$adrenoceptor-deficient mice. Naunyn Schmiedebergs Arch Pharmacol 364:117-130.

Trendelenburg AU, Philipp M, Meyer A, Klebroff W, Hein L, and Starke K (2003) All three $\alpha_{2}$-adrenoceptor types serve as autoreceptors in postganglionic sympathetic neurons. Naunyn Schmiedebergs Arch Pharmacol 368:504-512.

Wang M, Ramos BP, Paspalas CD, Shu Y, Simen A, Duque A, Vijayraghavan S, Brennan A, Dudley A, Nou E, et al. (2007) $\alpha_{2 \mathrm{~A}}$-Adrenoceptors strengthen working memory networks by inhibiting cAMP-HCN channel signaling in prefrontal cortex. Cell 129:397-410.

Wettschureck N and Offermanns S (2005) Mammalian G proteins and their cell type specific functions. Physiol Rev 85:1159-1204.

Address correspondence to: Dr. Lutz Hein, Institute of Experimental and Clinical Pharmacology and Toxicology, University of Freiburg, Albertstrasse 25, 79104 Freiburg, Germany. E-mail: lutz.hein@pharmakol.uni-freiburg.de 